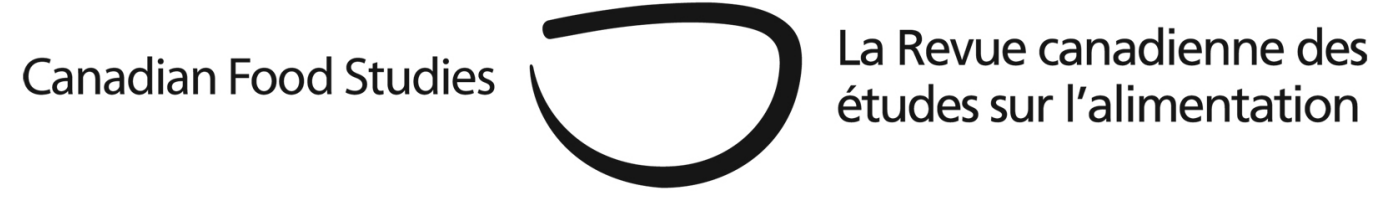

\title{
Commentary
}

\section{Building joined-up agricultural policies: Lessons from Québec}

\author{
Hugo Martorell and Elisabeth Abergel* \\ Université du Québec à Montréal
}

\section{Introduction}

Under existing policy frameworks in Canada, provincial and territorial governments are granted a certain degree of autonomy over social, health, and agricultural policy and spending. This makes the institutional landscape quite uneven in many areas that are relevant to a "joined-up" food policy. Competitive and overlapping jurisdictions often deter collaboration and integration between levels of government (MacRae, 2011). New governance and policy paradigms are required to shift towards more sustainable, just, and healthy food systems in Canada (Skogstad, 2012). Alison Blay-Palmer (2012) points to three supporting principles: the precautionary principle $^{1}$; multifunctionality, which seeks to support both economic and noneconomic outcomes of agriculture (environmental, rural, social); and, subsidiarity, “defined as appropriately scaled policy and interventions” (p.41). In this commentary, we explore ways in which Québec has integrated these operating principles in its policies and funding schemes.

Policy experiences of provinces and territories can inform policy development at the federal level (Martorell, 2017). For instance, British Columbia is regarded as a leader, with health prevention driving food policy change across departments (Seed, Lang, Caraher \& Ostry, 2013). In social policy, income-based supports and poverty reduction measures have been notably more successful in Newfoundland and Labrador (Taras uk, Mitchell, \& Dachner, 2014).

\footnotetext{
${ }^{1}$ In Québec law, the precautionary principle states, "where there is a risk of serious or irreversible harm, the lack of full scientific certainty should not be used as a reason for postponing the adoption of effective measures to prevent environmental degradation”(MDDEP, 2006).
} 
In Québec, food policy efforts have been studied through the lens of healthy eating (Addy, 2016), and food security (Hamelin \& Bolduc, 2003). This commentary, however, discusses how Québec’s unique approach in the Canadian context might provide lessons to build more integrated approaches to agriculture and rural policies.

\section{Institutional arrangements in sustainable food and farming in Québec}

Agricultural policy in Québec is distinct in relation to other provinces in Canada. One study on policy networks notes; it stands out as exceptional since it is the only province that has not hesitated to use intrusive and comprehensive command-and-control regulation and financial incentives (Montpetit and Coleman, 1999). As with other provinces, one key feature of agricultural governance in Québec is corporatism. This refers to the power of food producers and their organizational networks to influence officials in agricultural ministries (Skogstad, 2012). When comparing Québec’s agri-environmental policy networks with Ontario and North Carolina, Montpetit (1999) pointed to Québec’s relatively stronger performance. He argues that the institutional capacity of the farmers' union, the Union des Producteurs Agricoles (U.P.A.), was a facilitator to the adoption of agri-environmental policy. However, the UPA has also acted as an intermediary that has filtered pressures for reforms against those that have challenged its productivist standpoint (Benoit, 2015).

Québec's turn towards economic nationalism and a productivist paradigm in the 1970s was characterized by a centralized and top down approach to rural planning and the management of natural resources, such as farmland. Connell et al. (2016) assessment of land preservation regimes across Canada found Québec's to be the strongest, highlighting its flexible yet stable and integrated framework. The more recent provincial consultations (Pronovost Report in 2008 and the Ouimet Report in 2009), however, questioned the resiliency of the scheme to prevent urban sprawl (Vachon, 1991), and the ways in which it posed a barrier to farm renewal. Overall, greater evidence is needed on farmland use. Generating data on the loss of farmland, financial speculation, and changes to foreign ownership could represent a first step for provinces and federal government to work together on the issue (Connell et al., 2016).

The precautionary principle, multifunctionality, and, subsidiarity in Québec food policy

While Québec ranked behind British Columbia and Prince Edward Island as the third "greenest province” (Corporate Knights, 2014), it has made achievements integrating sustainable development, and the precautionary principle, into legal frameworks. "To date, the most elaborate and connected Canadian example [of comprehensive sustainability legislation] is Québec’s Sustainable Development Act” (Blay-Palmer, 2012, p.65). In theory, this principle 
could justify policy interventions in the field of agricultural inputs (e.g., pesticides and genetic engineered seeds) and livestock farming (e.g., hog manure pollution). Although legal precedents remain too few and, in the case of pesticides, limited to residential and cosmetic use ${ }^{2}$, they indicate that public health concerns at sub-national jurisdictions have the potential to influence scientific risk assessments in Canada (Pralle, 2006).

As environmental awareness increased during the 1990s, the Québec government externalized research and advisory services ${ }^{3}$ in its co-management agreement with the U.P.A. (Benoit 2015). The design of agri-environmental clubs is associated with an increase in the adoption of integrated pest management techniques and the development of large expanses of windbreaks to protect waterways in Québec (MacRae et al., 2004). These clubs have been instrumental for providing advice on organic food production, supporting on-farm research, and accompanying farmers in adopting beneficial management practices (BMPs). While many of those clubs have been privatized, they remain partly funded through cost-sharing schemes under current agricultural policy frameworks. The 2018 renewal of the federal agreement on agriculture should build on this model and invest in extension services in sustainable farming across the country.

An agro-ecological lens to Québec’s policy landscape points to policy interventions in organic farming, as well as rural development (Jolin, 2015). One mandate of rural extension services supported through Québec’s National Rural Policy (NRP) was focused on accompanying labelling schemes to designate regional origins of agricultural products associated with Québec's terroir (e.g., Charlevoix lamb, Neuville corn). The NRP is “one of the most advanced policy approaches to promote rural development in the OECD area" (OECD, 2010, p.17). Like in Europe, regional designation schemes should be privileged and recognized to ensure food quality and protect regional economies (Becker and Staus, 2008). In Québec, where these are in the early stages of development (Parent and Desjardins, 2015), a provincial council ${ }^{4}$ manages both regional and organic designations, illustrating some degree of institutional coordination that should be expanded at a federal level through its value chain roundtables.

An important facet of Québec's National Rural Policy (NRP) was its ability to tap into policy networks outside of government, most notably civil society actors coalescing around Solidarité Rurale, in the early stages of the process: "Since 1997, this organization is recognized as the advisory body to the government of Québec with regards to rural development” (Doddrige and Senechal, 2014, p.5). Despite its innovative character (OECD, 2010), however, the NRP agreement with civil society was not renewed by the new liberal provincial government (Vaillancourt, 2017).

Québec has also been the first province to adopt a full strategic plan in the organic food and farming sector "that rival[s] plans in Europe" (MacRae et al., 2004). The most recent

\footnotetext{
${ }^{2}$ The Hudson v. Spraytech Supreme Court Ruling (2001) to ban lawn pesticides in the municipality of Hudson, Québec is a seminal case of appealing to the precautionary principal in Canada.

${ }^{3}$ These institutions were respectively known as the Institut de Recherche en Agroenvironnement and the ClubConseils Agroenvironmentaux.

${ }^{4}$ The Reserved Designations and Added-Value Claims Board was implemented via legislation in 2006.
} 
iteration of the strategy (2015) incorporates multifunctionality. It also represents a positive step towards integration with agri-environmental policy, another piece of the agricultural policy generally conceived in a silo. The strategy brings together a mix of policy instruments from both areas, including support for organic transition, extension services, and research. The institutional capacity of farming bodies was brought in to facilitate coordination ${ }^{5}$ across commodity groups to advance organic food and farming in their respective sectors (e.g., poultry, eggs, etc.). Such a mandate could be extended to the Farm Products Council and across value chain roundtables, which are under federal jurisdiction.

Québec's experience in creating regional cooperation mechanisms applies the principle of subsidiarity by decentralizing decision making at appropriate levels of governance. ${ }^{6}$ Regional development mandates and agricultural land use plans embodied the principles of multifunctionality and participative planning (Doucet, 2010; Doyon, Desrosiers-Côté, \& Loyer, 2016). In the 1990s, the government supported the creation of seventeen agri-food roundtables, which were "mandated to bring together all actors in the food industry within a specific region" (Ashraf \& Konforti, 2010, p. 12). A review of the seventeen regional action plans of another set of regional public sector bodies ${ }^{7}$ indicated that 60 percent of orientations were aligned with a multifunctional paradigm to agriculture (Doucet, 2010). Finally, regional and county-wide ${ }^{8}$ agricultural land use plans are contributing to anchor agricultural and food governance on a territorial basis (Doyon et al., 2016) with mandates to diversify farming activities, promote short supply chains, and institute participative planning mechanism. In Canada, the six regional development agencies under the Innovation, Science and Economic Development portfolio ${ }^{9}$ are particularly well suited to build on these to invest in local and sustainable food systems.

\section{Conclusion}

We have focused our commentary on three key operating principles that have been integrated, to varying degrees, into Québec’s agricultural policy - the precautionary principle, multifunctionality and subsidiarity - thereby providing opportunities for linking agricultural and food policy processes more effectively. This integration is only partial because a number of the programs mentioned remain marginal ( $<1$ percent) within the overall provincial budget for agriculture (Benoit, 2015), and are subject to the same “neoliberal governmentalities” Andrée,

\footnotetext{
${ }^{5}$ The Organic sector growth roundtable was launched by tbe main farming organization in 2014.

${ }^{6}$ This level of administrative governance is located between the municipal, or county-level, and provincial jurisdictions. There are seventeen in Québec

${ }^{7}$ These bodies were known as as Regional development councils until 2004, when they were changed into the Conference of regional elected officials, before being dissolved by provincial reform in 2014.

${ }^{8}$ In Québec, counties are called Regional County of Municipalities (RCM)

${ }^{9}$ The agencies are the Northern Economic Development Agency, the Western Economic Diversification Canada, Canadian Northern Economic Development Agency, Federal Economic Development Agency for Northern (FedNord) and Southern Ontario (FedDev Ontario), Canada Economic Development for Québec Regions and the Atlantic Canada Opportunities Agency
} 
Ballamingie, and Sinclair-Waters (2014) identify in Ontario. New operating principles continue to be needed to build policy and governance from the ground up. Ideally, agricultural policy must integrate across health, social, rural and environmental mandates. Québec has only taken small steps towards this larger goal. With these reservations in mind, Québec still provides examples of implementing policy to try and fill what has been an institutional void in the area of food policy. Its experience may therefore be of comparative value to other jurisdictions. In particular, key federal institutions could adopt a horizontal approach that builds on the experience of Québec with the precautionary principle, multifunctionality, and subsidiarity. Questions about how to achieve vertical policy integration between the provinces and national policy will arise. The 2018 unveiling of a new Québec “bio-food” policy (2018-2025), alongside the renewal of the Canadian Agricultural Partnership, ensure that these questions will need to be front-of-mind for observers as the federal government moves forward on a Food Policy for Canada. Our hope is that Québec and Canada will find a way to work together across these three overlapping policies (among others) in the spirit of a "joined-up" (MacRae, 2011) approach that benefits citizens in both jurisdictions.

\section{References}

Andrée, P., Ballamingie, P., \& Sinclair-Waters, S. (2014). Neoliberalism and the making of food politics in Eastern Ontario. Local Environment: The International Journal of Justice and Sustainability, 20(12), 1-21.

Ashraf, K., \& Konforti, L. (2010) Scaling up local food systems in Québec and Ontario: Actors, institutions, and change in the governance of two regional food systems. A report by Équiterre and the Center for Trade Policy and Law, 50 pages.

Becker, T., \& Staus, A. (2008). European food quality policy: the importance of geographical indications, organic certification and food quality insurance schemes in European countries. Paper prepared for presentation at the 12th EAAE Congress 'People, Food and Environments: Global Trends and European Strategies’, Gent (Belgium), 26-29 August 2008.

Benoit, M. (2015) Reconfiguration de l'État et renouvellement de l'action publique agricole : L'évolution des politiques agroenvironnementales au Québec et en France. Droit. Université Montpellier.

Blay-Palmer, A. (2012). Alternative Land Use Services and the Case for Multifunctional Policy in Canada. In: R.J. MacRae \& E. Abergel (eds). Health and Sustainability in the Canadian Food System: Advocacy and Opportunity for Civil Society (pp. 39-69). Vancouver=: UBC Press.

Canada Ltée (Spraytech, Société d’arrosage) v. Hudson (Town), 2001 S.C.C. 40 at paras. 84-27 [Hudson v. Spraytech]. 
Connell, D.J., Caldwell, W., Bryant, C., Cameron, G., Johnston, T., and Margulis, M. (2016). Farmland: A prerequisite for farmers, food - and agri-food policy. Policy Brief. Retrieved from: http://blogs.unbc.ca/agplanning/files/2013/09/Policy-Brief-FarmlandProtection-in-Canada-Aug-20163.pdf

Corporate Knights (2014). 2014 Green provinces and states. Retrieved from, http://www.corporateknights.com/reports/2014-green-provinces-states/green-crown-goes$14017173 /$

Desmarais, A.A., \& Wittman, G. (2014): Farmers, foodies and First Nations: getting to food sovereignty in Canada, The Journal of Peasant Studies, 41(6), 1-21.

Doddridge, H., \& Sénéchal, E. (2013). Débats publics, nouveaux dialogues et consensus: vers une politique de souveraineté alimentaire au Québec. Nouvelles formes d'agriculture: pratiques ordinaires, débats publics et critique sociale: Dijon, France.

Doucet, C. (2010). L’agriculture dans les plans régionaux de développement des Conférences régionales des élus : vision multifonctionnelle ou productiviste ? Cahier de l'Alliance de recherche université-communauté en Innovation sociale et développement des communautés. Série "Recherches”, 30.

Doyon, M., Desrosiers-Côté, M., \& Loyer, F. (2016). Les PDZA : un renouvellement de la gouvernance agricole. Revue Vie Économique, 8(1),1-9.

Hamelin, A.M., \& Bolduc, N. (2003) La sécurité alimentaire à l’agenda politique québécois. Revue Service Social, 50(1), 57-80.

Jolin, Z. B, (2015). Le développement de l’agroécologie au Québec: Re-définir les paradigmes agricoles. Maitrise en environement, Université de Sherbrooke.

MacRae, R., Martin, R., Macey, A., Doherty, P., Gibson J., \& Beauchemin, R. (2004) How governments in other jurisdictions successfully support the development of organic food and farming. Retrieved from: http://www.organicagcenter.ca/DOCs/Paper_Supports_Version2_rm.pdf

Ministère du Développement durable, Environnement et Parcs (MDDEP). (2006) Loi sur le Développement durable: Chapitre II, article 6.

Montpetit, É., \& Coleman, W.D. (1999). Policy communities and policy divergence in Canada: Agro-environmental policy development in Québec and Ontario. Canadian Journal of Political Science, 32(4). 691-714.

OECD (2010), OECD Rural policy reviews: Québec, Canada 2010, OECD Rural Policy Reviews, OECD Publishing, Paris, https://doi.org/10.1787/9789264082151-en.

Parent, G., \& Desjardins, M.C. (2015). Le droit et les systèmes alimentaires territorialisés : perspective canadienne. Économies et Sociétés, Série "Systèmes agroalimentaires", 37(8), 1185-1201. 
Pralle, S. (2006). The "Mouse that roared”: Agenda-setting in Canadian pesticides politics. The Policy Studies Journal, 34(2): 171-194.

Seed, B., Lang, T., Caraher, M., \& Ostry, A. (2013). Integrating food security into public health and provincial government departments in British Columbia, Canada. Journal of Agriculture and Human Values 30, 457-470.

Skogstad, G. (2012). Effecting paradigm change in the Canadian agriculture and food sector: Towards a multifunctionality paradigm. In R.J. MacRae \& E. Abergel (Eds). Health and Sustainability in the Canadian Food System: Advocacy and Opportunity for Civil Society (pp.17-38). Vancouver, BC: UBC Press.

Tarasuk, V, Mitchell, A, Dachner, N. (2016). Household food insecurity in Canada, 2014.Toronto: Research to identify policy options to reduce food insecurity (PROOF). Retrieved from http://proof.utoronto.ca/

Vachon, B. (Ed.). (1991). Le Québec rural dans tous ses états. Québec: Les Éditions Boréal.

Vaillancourt, Y. (2017). Marges de manœuvre des acteurs locaux de développement social en contexte d'austérité. Cahiers du Centre de recherche sur les innovations sociales. Collection "Études théoriques et méthodologiques", ET1701. 